\title{
Assessment of genetic diversity among strains of Xanthomonas campestris pv. manihotis
}

\author{
V. VERDIER, ${ }^{1 *}$ P. DONGO ${ }^{2}$ and B. BOHER ${ }^{3} \dagger$ \\ 'ORSTOM, Laboratoire de Phytopathologie, BP 5045, 34032 Montpellier, France \\ ${ }^{2}$ ORSTOM, Laboratoire de Phytopathologie, BP 181 Brazzaville, Congo \\ ${ }^{3}$ ORSTOM, Laboratoire de Phytopathologie, BP 375 Lomé, Togo
}

(Received 19 May 1993; revised 8 July 1993; accepted 15 July 1993)

\begin{abstract}
Three-hundred and twenty-six strains of Xanthomonas campestris pv. manihotis from 22 countries were studied to detect and assess genetic and evolutionary relationships within the pathovar. A range of techniques was used for this study including restriction fragment length polymorphism (RFLP) analysis. The probes used for the RFLP analysis were 16+23S rRNA genes from Escherichia coli and three restriction fragments from the chromosomal and plasmid DNA of $X$. campestris pv. manihotis. Analysis of the rRNA probe data showed five RFLP groups whilst the other three probes were used to further sub-divide these groupings. Genetic variability of $X$. campestris pv. manihotis was pronounced in strains from South America where the host plant originated but was limited in strains from other regions. The results obtained confirm the hypothesis that the pathogen has been introduced only recently to Africa and suggests that African strains have not as yet diversified significantly at the chromosomal level. Our results indicate that rRNA and DNA probes are useful tools for epidemiological studies and in following the genetic evolution of strains.
\end{abstract}

\section{Introduction}

Xanthomonas campestris pv. manihotis is the causal agent of cassava bacterial blight. Symptoms are characterized by an angular leaf spot and a systemic infection of the stem which leads to wilting and die-back. This disease causes severe yield losses in cassava growing areas (Lozano \& Sequeira, 1974a). Cassava bacterial blight was first reported in Brazil in 1912 (Bondar, 1912). It was observed in Colombia and Venezuela in 1971 (Lozano \& Sequeira, 1974b) and has occurred in most African and Asian countries since 1972 (Williams et al., 1973; Maraite \& Meyer, 1975; Booth \& Lozano, 1978).

Several reports (Lozano \& Sequeira, 1974a; Maraite et al., 1981; Grousson et al., 1990) have demonstrated differences among strains of $X$. campestris pv. manihotis based on pathogenicity, physiological and biochemical characteristics. Plasmid profiles have also been reported

\footnotetext{
*Author for correspondence. Tel. +3367617587 ; fax +336754 7800 .
}

$\dagger$ Present address: ORSTOM, Laboratoire de Phytopathologie, BP 5045, 34032 Montpellier, France.

Abbreviation: RFLP, restriction fragment length polymorphism. to be variable among strains of $X$. campestris pv. manihotis (Verdier, 1988). In contrast, studies based on protein electrophoretic analysis (Vauterin et al., 1991) and DNA homology, (Van den Mooter et al., 1987) have indicated that $X$. campestris pv. manihotis constitutes a genetically and phenotypically homogeneous group of bacteria.

RFLP analysis has been used to differentiate plantpathogenic bacteria at the pathovar level (Lazo \& Gabriel, 1987; Denny et al., 1988; Leach et al., 1990; Qhobela et al., 1990) as well as to assess relatedness among bacterial strains (Gabriel et al., 1988; Cook et al., 1989, 1991; Hartung \& Civerolo, 1989; Leach et al., 1992; Pruvost et al., 1992; Qhobela et al., 1991; Qhobela \& Claflin, 1992; Xu \& Gonzales, 1991). The conserved nature of rRNA genes allowed the use of a $16+23 \mathrm{~S}$ rRNA probe from Escherichia coli for the identification of bacteria and for taxonomic studies (Grimont et al., 1989). This probe was used for phylogenetic studies of human pathogenic bacteria (Scieux et al., 1992) and recently of phytopathogenic bacteria (Berthier et al., 1993). It has been established previously on a small number of strains, that the Escherichia coli $16+23 \mathrm{~S}$ rRNA probe was a useful probe to detect restriction polymorphisms in the $X$. campestris pv. manihotis genome (Berthier et al., 1993). This study has been 
Table 1. Strains of $X$. campestris pv. manihotis

\begin{tabular}{|c|c|c|c|}
\hline Strain no. and reference in other collections* & Origin & $\begin{array}{l}\text { Year of } \\
\text { isolation }\end{array}$ & Isolated by \\
\hline LMG 776 (NCPPB 2443, HMB 72, CFBP 2603) & Colombia & 1970 & \\
\hline ORST 1 (CIAT 1060, CFBP 1849) & Colombia & 1970 & \\
\hline CIAT 1058 & Colombia & 1970 & \\
\hline NCPPB 2444 & Colombia & 1970 & J. Lozano (CIAT) \\
\hline CFBP 1851 (CIAT 1111) & Colombia & 1974 & \\
\hline CIAT 1199 & Colombia & 1981 & \\
\hline CIAT 1222 & Colombia & 1984 & \\
\hline ORST 211 & Colombia & 1992 & $\begin{array}{l}\text { V. Verdier (This } \\
\text { laboratory) }\end{array}$ \\
\hline ORST 2 (CIAT 1061, CFBP 1850) & Venezuela & 1971 & J. Lozano (CIAT) \\
\hline CIAT 1129 & Venezuela & 1974 & \\
\hline ATCC 23380 (HMB 68, NCPPB 1159) & Brazil & 1941 & $\begin{array}{l}\text { W. H. Burkholder (New } \\
\text { York, USA) }\end{array}$ \\
\hline HMB 70 (NCPBB 1160, LMG 5273) & Brazil & 1941 & $\begin{array}{l}\text { O. A. Drummond, O. } \\
\text { Hipolito (LMG) }\end{array}$ \\
\hline NCPPB 348 & Brazil & 1954 & M. P. Starr (Davis, USA) \\
\hline HMB 55a (NCPBB 1834†, LMG 784) & Brazil & 1965 & $\begin{array}{l}\text { C. Robbs (Rio de Janeiro, } \\
\text { Brazil) }\end{array}$ \\
\hline CIAT 1065 & Brazil & 1971 & J. Lozano (CIAT) \\
\hline NCPPB 2550 & Brazil & 1973 & A. L. G. Pereira (NCPBB) \\
\hline ORST 7 (CFBP 1854) & Brazil & 1973 & J. R. Neto (CFBP) \\
\hline HMB 23 (LMG 770) & Brazil & 1973 & A. L. G. Pereira (NCPBB) \\
\hline CIAT 1117 & Brazil & 1974 & J. Lozano (CIAT) \\
\hline ORST 3 (CIAT 1120, CFBP 1852) & Brazil & 1974 & \\
\hline ORST 5 (CFBP 1855) & Brazil & 1974 & J. R. Neto (CFPB) \\
\hline ORST 6 (CFBP 1856) & Brazil & $\begin{array}{l}1976 \\
1078\end{array}$ & \\
\hline & Brazil & $\begin{array}{l}1978 \\
1978\end{array}$ & \\
\hline $\begin{array}{l}\text { LMG } 777 \text { (HMB 78) } \\
\text { LMG } 779 \text { (HMB 80) }\end{array}$ & $\begin{array}{l}\text { Brazil } \\
\text { Brazil }\end{array}$ & $\begin{array}{l}1978 \\
1978\end{array}$ & \\
\hline UnB 64 & Brazil & 1978 & \\
\hline UnB 9 & Brazil & 1980 & \\
\hline UnB 49 & Brazil & 1980 & \\
\hline UnB 129 & Brazil & 1981 & \\
\hline UnB 184 & Brazil & 1981 & \\
\hline UnB 185 & Brazil & 1982 & A. Takatsu (Brasilia, \\
\hline UnB 215 & Brazil & 1982 & Brazil) \\
\hline UnB 216 & Brazil & 1982 & \\
\hline UnB 289 & Brazil & 1982 & \\
\hline UnB 291 & Brazil & 1983 & \\
\hline UnB 351 & Brazil & 1983 & \\
\hline UnB 589 & Brazil & 1985 & \\
\hline UnB 638 & Brazil & 1986 & \\
\hline UnB 724 & Brazil & 1988 & \\
\hline UnB 833 & Brazil & 1991 & \\
\hline CIAT 1162 & Mexico & 1976 & J. Lozano (CIAT) \\
\hline HMB 25 (NCPBB 3060, LMG 771) & Nigeria & 1976 & $\begin{array}{l}\text { H. Maraite (Louvain, } \\
\text { Belgium) }\end{array}$ \\
\hline ORST 42 & Nigeria & 1978 & \\
\hline ORST 43 & Nigeria & 1978 & \\
\hline CFBP 1857 (ORST A202.1) & Nigeria & 1978 & \\
\hline CFBP 1858 (ORST A203.1) & Nigeria & 1978 & \\
\hline CFBP 1859 (ORST A205.1) & Nigeria & 1978 & J. F Daniel (This \\
\hline CFBP 1860 (ORST A207) & Nigeria & 1978 & laboratory) \\
\hline ORST 34 & Benin & 1982 & \\
\hline ORST 35 & Benin & 1982 & \\
\hline ORST 36 & Benin & 1982 & \\
\hline ORST 37 & Benin & 1982 & \\
\hline $\begin{array}{l}\text { ORST } 38 \\
\text { CFBP } 1944\end{array}$ & Benin & 1982 & \\
\hline $\begin{array}{l}\text { CFBP } 1944 \\
\text { LMG } 5249 \text { (HMB 203) }\end{array}$ & $\begin{array}{l}\text { Ivory Coast } \\
\text { Ivory Coast }\end{array}$ & $\begin{array}{l}1979 \\
1981\end{array}$ & $\begin{array}{l}\text { M. Ride (Angers, France) } \\
\text { H. Maraite (Louvain, }\end{array}$ \\
\hline LMG 5249 (HMB 203) & Ivory Coast & 1981 & $\begin{array}{l}\text { H. Maraite (Louvain, } \\
\text { Belgium) }\end{array}$ \\
\hline ORST 55 & Ivory Coast & 1984 & J. F. Daniel (This \\
\hline ORST 56 & Ivory Coast & 1984 & laboratory) \\
\hline 198 strains from ORST & Congo & $1977-1992$ & $\begin{array}{l}\text { B. Boher, J. F. Daniel, } \\
\text { V. Verdier (This } \\
\text { laboratory) }\end{array}$ \\
\hline
\end{tabular}


Table 1 (cont.)

\begin{tabular}{|c|c|c|c|}
\hline Strain no. and reference in other collections* & Origin & $\begin{array}{l}\text { Year of } \\
\text { isolation }\end{array}$ & Isolated by \\
\hline 29 strains from ORST & Togo & $1987-1991$ & $\begin{array}{l}\text { B. Boher, V. Verdier (This } \\
\text { laboratory) }\end{array}$ \\
\hline HMB 6 (LMG 767) & Zaire & 1973 & \\
\hline HMB 9 (LMG 768, NCPBB 3058) & Zaire & 1973 & H. Maraite (Louvain, \\
\hline LMG 769 (NCPPB 3059, HMB 10) & Zaire & 1973 & Belgium) \\
\hline LMG 766 (HMB 3) & Zaire & 1973 & \\
\hline ORST 44 & Zaire & 1979 & \\
\hline ORST 45 & Zaire & 1979 & \\
\hline ORST 46 & Zaire & 1979 & \\
\hline ORST 47 & Zaire & 1979 & \\
\hline ORST 48 & Zaire & 1979 & \\
\hline ORST 49 & Zaire & 1979 & $\begin{array}{l}\text { J. F. Daniel (1 his } \\
\text { laboratory) }\end{array}$ \\
\hline ORST 50 & Zaire & 1979 & \\
\hline ORST 51 & Zaire & 1979 & \\
\hline ORST 52 & Zaire & 1979 & \\
\hline ORST 53 & Zaire & 1979 & \\
\hline ORST 54 & Zaire & 1979 & \\
\hline ORST 186 & Zaire & 1987 & B. Boher (This laboratory) \\
\hline ORST 187 & Zaire & 1987 & \\
\hline ORST 39 & Central Africa & 1977 & J. F. Daniel (This \\
\hline ORST 40 & Central Africa & 1977 & laboratory) \\
\hline ORST 41 & Central Africa & $\begin{array}{l}1977 \\
1976\end{array}$ & G. Perslev (LMG) \\
\hline LMG 5287 (NCPPB 3161) & Cameroon & 1976 & G. Persiey (LMU) \\
\hline HMB 27 (LMG 629) & Cameroon & 1977 & $\begin{array}{l}\text { H. Maraite (Louvain, } \\
\text { Belgium) }\end{array}$ \\
\hline ORST 212 & Cameroon & 1992 & \\
\hline ORST 213 & Cameroon & 1992 & \\
\hline ORST 214 & Cameroon & 1992 & V. Verdier (This \\
\hline ORST 215 & Cameroon & 1992 & laboratory) \\
\hline ORST 216 & Cameroon & 1992 & \\
\hline ORST 217 & Cameroon & 1992 & \\
\hline LMG 780 (HMB 81) & Uganda & 1979 & H Maraite (Louvain \\
\hline LMG 782 (HMB 93) & Uganda & 1979 & $\begin{array}{l}\text { Belgium) } \\
\text { Butam, }\end{array}$ \\
\hline LMG 783 (HMB 148) & Kenya & $1979 J$ & \\
\hline LMG 5288 (NCPPB 3194) & Niger & 1978 & J. Bradbury (Kew, UK) \\
\hline CIAT 1160 & Malaysia & 1976 & J. Lozano (CIAT) \\
\hline LMG 765 & Malaysia & 1980 & G. Lan (LMG) \\
\hline CIAT 1135 & Taiwan & 1975 & J. Lozano (CIÁT) \\
\hline LMG 774 (HMB 60) & Taiwan & 1978 & $\begin{array}{l}\text { H. Maraite (Louvain, } \\
\text { Belgium) }\end{array}$ \\
\hline CIAT 1163 & Sumatra & 1976 & \\
\hline CIAT 1181 & Philippines & 1977 & J. Lozano (CIAT) \\
\hline CIAT 1203 & Dominican Rep. & 1981 & \\
\hline HMB 71 (NCPBB 1161, LMG 775) & Mauritius & 1946 & G. Orian (LMG) \\
\hline CFBP 2624 & Reunion Island & 1986 & $\begin{array}{l}\text { O. Pruvost (CIRAD, } \\
\text { La Réunion) }\end{array}$ \\
\hline CFBP 2635 & Reunion Island & 1987 & $\begin{array}{l}\text { J. C. Girard (CIRAD, } \\
\text { La Réunion) }\end{array}$ \\
\hline
\end{tabular}

*Abbreviations: ATCC, American Type Culture Collection, Rockville, MD, USA; CFBP, Collection Française de Bactéries, Phytopathogènes, Angers, France; CIAT, Xanthomonas collection, Centro International de Agricultura Tropical, Cali, Colombia; HMB, Collection of H. Maraite, Louvain La Neuve, Belgium; LMG, Laboratorium voor Microbiologie Gent Culture Collection, Universiteit Gent, Belgium; NCPPB, National Collection of Plant Pathogenic Bacteria, Harpenden, UK; ORST, Collection du Laboratoire de Phytopathologie, ORSTOM, Brazzaville, Congo; UnB, Collection of A. Takatsu, Universidade Nacional de Brasilia, Brazil.

$\dagger$ A pathovar reference strain.

extended here to a total of 326 strains of $X$. campestris pv. manihotis from worldwide geographical locations, to assess genetic diversity and evolutionary relationships with special emphasis on the African population of the pathogen. Different techniques were used to distinguish strains of $X$. campestris pv. manihotis including biochemical characteristics, pathogenicity tests on host plants and restriction fragment length polymorphism 
(RFLP) analyses of genomic DNA. Probes used for RFLP studies reported here were evaluated for their utility for genetic characterization and in epidemiological studies of $X$. campestris pv. manihotis.

\section{Methods}

Bacterial strains. Three-hundred and twenty-six strains of $X$. campestris pv. manihotis isolated from Manihot esculenta in 22 countries were used in this study. The sources and geographical origin of the bacterial strains are listed in Table 1. The 29 strains from Togo and 198 strains from the Congo were isolated from samples collected in different ecological zones and at different times. Control strains of $X$. campestris pv. cassavae (HMB 29), X. campestris pv. phaseoli (CIAT 214), $X$. campestris pv. malvacearum (NCPPB 633) and $X$. campestris pv. undulosa (UPB 670) were included in the RFLP study. All strains were stored as frozen glycerol stocks and were maintained on YPGA medium $\left(1^{-1}: 5 \mathrm{~g}\right.$ yeast extract, $5 \mathrm{~g}$ Bactopeptone, $5 \mathrm{~g}$ glucose, $15 \mathrm{~g}$ agar, $\mathrm{pH}$ adjusted to $7 \cdot 2$ ).

Phenotypic studies. Starch hydrolysis was carried out using a medium containing $0.5 \%(\mathrm{w} / \mathrm{v})$ yeast extract, $0.5 \%(\mathrm{w} / \mathrm{v})$ Bactopeptone, $0.2 \%$ $(\mathrm{w} / \mathrm{v})$ soluble starch and $1.5 \%(\mathrm{w} / \mathrm{v})$ agar in distilled water. Tests were inoculated with a drop of a suspension of approximately $10^{9}$ cells $(\mathrm{ml}$ distilled water) $)^{-1}$. After $5 \mathrm{~d}$ incubation at $30^{\circ} \mathrm{C}$, Lugol iodine solution was poured on the plates. Starch hydrolysis was indicated by the presence of clear zones in the black-stained medium around the colonies. The in vitro susceptibility towards 20 antibiotics was determined by the technique described by Grousson et al. (1990), using sensitivity bio-discs (bioMerieux). The following antibiotics were tested (per disk): $10 \mu \mathrm{g}$ ampicillin, $30 \mu \mathrm{g}$ cefuroxime, $25 \mu \mathrm{g}$ amoxicillin, $30 \mu \mathrm{g}$ cefotaxime, $30 \mu \mathrm{g}$ kanamycin, $10 \mathrm{U}$ penicillin $\mathrm{G}, 10 \mu \mathrm{g}$ streptomycin, $300 \mathrm{U}$ polymixin $\mathrm{B}, 30 \mu \mathrm{g}$ chloramphenicol, $100 \mu \mathrm{g}$ carbenicillin, $30 \mu \mathrm{g}$ cefalotin, $30 \mu \mathrm{g}$ cefoxitin, $15 \mu \mathrm{g}$ erythromycin, $30 \mu \mathrm{g}$ neomycin, $30 \mu \mathrm{g}$ nalidixic acid, $30 \mu \mathrm{g}$ rifampicin, $250 \mu \mathrm{g}$ sulfamide, $30 \mu \mathrm{g}$ tetracycline, $75 \mu \mathrm{g}$ ticarcillin and $15 \mu \mathrm{g}$ virginiamycin. Inhibition zones were recorded after $48 \mathrm{~h}$ according to the manufacturer's recommendations (bioMerieux). Utilization of carbon sources was tested using the basal medium of Hayward (1964). The following carbon sources were sterilized separately by filtration and were tested at the recommended concentration of $0.2 \%(\mathrm{w} / \mathrm{v})$ (Grousson et al., 1990): amidon, Dgalactose, ribose, glycerol, xylose, cellobiose, L-rhamnose, arabinose, maltose, lactose, trehalose, mannose, raffinose, esculin, D-fructose, saccharose, D-glucose, salicin and erythritol.

Phytopathogenicity tests. Pathogenicity of all strains of $X$. campestris pv. manihotis was tested on the cassava cultivar Mpembé from the Congo. This was propagated from cuttings. Inoculations were done according to methods described by Maraite et al. (1981). The development of symptoms was monitored over 1 month, and the observed reactions rated according to a scale described by Grousson $e t$ al. (1990). Three plants were inoculated with a given strain.

RFLP analysis, restriction digests, electrophoresis and blotting. Bacteria were cultured in a liquid medium containing peptone $\left(10 \mathrm{~g} \mathrm{l}^{-1}\right)$, casamino acids $\left(1 \mathrm{~g} \mathrm{l}^{-1}\right)$ and yeast extract $\left(\mathrm{g}^{-1}\right)$ ( $\mathrm{pH}$ adjusted to $7 \cdot 2$ ). Total genomic DNA was extracted from overnight cultures by the method of Boucher et al. (1985). DNA (5 $\mu \mathrm{g})$ was digested with the restriction endonuclease EcoRI according to the manufacturer's specifications (Eurogentec). Electrophoresis of DNA was carried out in $0.7 \%$ agarose gels in TBE buffer at $3 \mathrm{~V} \mathrm{~cm}^{-1}$ for $12 \mathrm{~h}$. Capillary transfers were performed either to Hybond $\mathrm{N}^{+}$following manu- facturer's specifications (Amersham) or to nitrocellulose membrane as described by Southern (1975).

Screening for probes. A genetic library was constructed by ligation of EcoRI fragments of strain $X$. campestris pv. manihotis CFBP 1851 into the vector Bluescript M13 (Maniatis et al., 1982). Two DNA clones, pBS6 and pBS8, which have a 6 and $8 \mathrm{~kb} E c o$ RI insert, respectively, were selected from the genomic library of strain $X$. campestris pv. manihotis CFBP 1851. These clones allowed the detection of polymorphism in the genome of strains of $X$. campestris pv. manihotis.

A CsCl-purified plasmid DNA ( $44 \mathrm{~kb}$ ) from the same strain was also digested with HindIII and fragments were separated using agarose gel electrophoresis. They were visualized with ultraviolet light $(320 \mathrm{~nm})$ after staining gels for 15 min in $1 \mathrm{mg}$ ethidium bromide $\mathrm{l}^{-1}$. A $13 \mathrm{~kb}$ HindIII fragment was excised from the agarose gel and eluted with glassmilk (Bio 101) before ligation into vector Bluescript M13. It has been shown that this DNA fragment (pBSF2) contains pathogenicity genes of $X$. campestris pv. manihotis (V. Verdier, unpublished data).

Competent $E$. coli cells (strain DH5 $\alpha$ ) were transformed with the different ligation mixtures and plated on Luria broth medium supplemented with ampicillin at $100 \mu \mathrm{g} \mathrm{m}^{-1}$ and with Xgal at $30 \mu \mathrm{g} \mathrm{ml}^{-1}$. White colonies were screened for inserts using the boiling mini-prep method (Maniatis et al., 1982). Large-scale preparations of recombinant DNA (insert with vector) were made by the alkaline lysis method and purified by precipitation with polyethylene glycol (Maniatis et al., 1982). Concentrations of recombinant DNA were calculated by measurement of $A_{260}$.

Hybridization procedure. The recombinant Bluescript plasmids were labelled with $\left[{ }^{32} \mathrm{P}\right]$ deoxycytidine triphosphate by random priming (Multiprime, Amersham). Prehybridization and hybridization ( $2 \mathrm{~h}$ ) of Southern blots were performed at $65^{\circ} \mathrm{C}$ in conditions described by the manufacturer (Amersham). Two post-hybridization stringency washes were done with $0.1 \% \mathrm{SSC}(1 \times \mathrm{SSC}=0.15 \mathrm{M}$-sodium chloride and $0.015 \mathrm{M}$-sodium citrate, $\mathrm{pH} 7.0$ ), $0.1 \% \mathrm{SDS}$ at $65^{\circ} \mathrm{C}$ for $20 \mathrm{~min}$ each. Autoradiography was done at $-80^{\circ} \mathrm{C}$ with X-Ray film (HyperfilmMP, Amersham) with intensifying screens (Amersham). All the experiments were done at least twice for each strain.

Hybridization with acetyl amino fluorene (AAF)-labelled ribosomal $16+23 S$ rRNA genes from $E$. coli and AAF-labelled pBR322 DNA, which hybridizes to the molecular mass marker Raoull, was performed according to the manufacturer's recommendations (Eurogentec). The presence or absence of specific restriction fragments was observed on autoradiograms and on the nitrocellulose membrane, and the size was estimated from the reference marker (RaoulI).

Hierarchical cluster analysis. A computer program (Miller, 1992) was used for calculating genetic distances between the strains based on fragment data. Fragment data were entered as fragment sizes in $\mathbf{k b}$. The Nei coefficient (Nei, 1987) was calculated for each strain and cluster analysis was done by the unweighted pair group method (UPGMA) using the Restsite program (Miller, 1992).

\section{Results}

\section{RFLP patterns}

Using the $16+23 \mathrm{~S}$ rRNA probe, five different patterns were obtained from the 326 strains tested. Two of the hybridizing fragments ( 9 and $1.5 \mathrm{~kb}$ ) were common to all the 326 strains. The other seven fragments $(10,7 \cdot 4,7,3 \cdot 6$, $2 \cdot 3,2,1.9 \mathrm{~kb}$ ) allowed the distinction of the five patterns (RNA groups 1, 2, 3, 4, 5) (Fig. 1). 


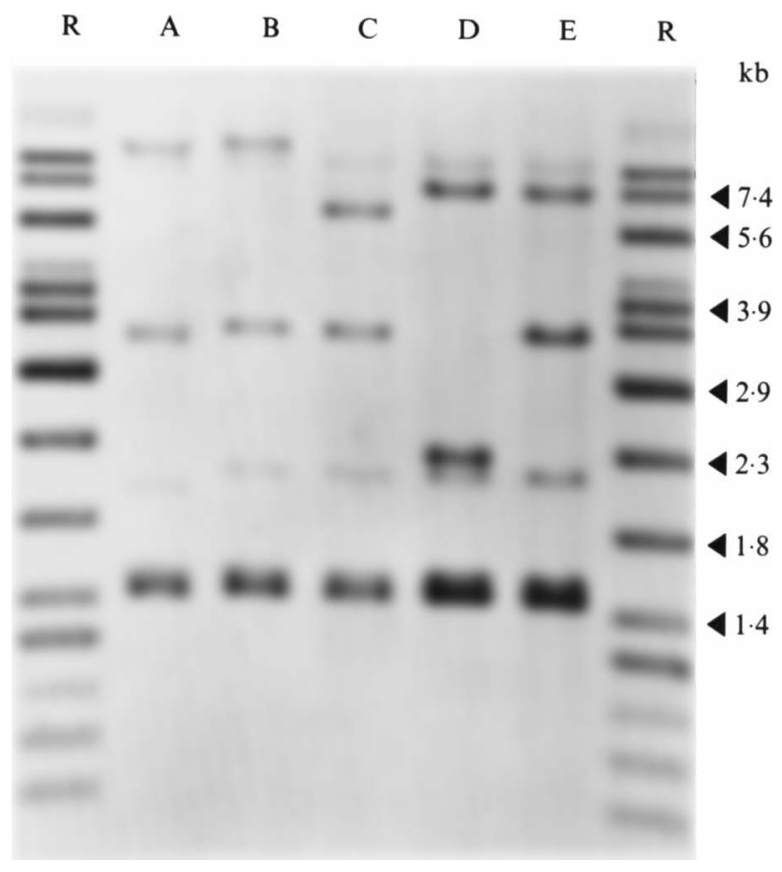

Fig. 1. Southern hybridization of EcoRI-digested genomic DNA of $X$. campestris pv. manihotis probed with AAF-labelled $16+23 \mathrm{~S}$ rRNA genes from $E$. coli and AAF-labelled $\mathrm{pBr} 322 \mathrm{DNA}$. All 326 strains used exhibited one of these five representative patterns each corresponding to an RNA group. Lanes: A, strain CFBP 1851 (Colombia), RNA group 3 ; B, strain ATCC 23380 (Brazil), RNA group 4; C, strain LMG 777 (Brazil), RNA group 2; D, strain NCPPB 2444 (Colombia), RNA group 5; E, strain CIAT 1163 (Sumatra), RNA group 1; R, molecular mass standard RaoulI.

The cluster analysis resulted in five groups, each group represented strains with identical RFLP patterns (Fig. 2). The rRNA probe did not show any polymorphism among the 271 African strains (Table 2). A representative strain from each African country was subsequently used to construct the dendrogram (Fig. 2). Strains belonging to RNA groups 2, 3 and 4 were located on the same branch of the phylogenetic tree and may be closely related. Strains in RNA groups 1 and 5 were more distantly related. In contrast to the homogeneous African strains (RNA1), those from South America were heterogeneous and gave the five different patterns (RNA groups $1,2,3,4,5)$. X. campestris pv. phaseoli, pv. malvacearum, pv. cassavae and pv. undulosa groups were clearly distinct from the $X$. campestris pv. manihotis groups.

The three DNA probes, pBS8, pBS6 and pBSF2 allowed the distinction of different subgroups within the five RNA groups defined above (Table 2).

Hybridization profiles with the pBS8 probe revealed different patterns. Two or three distinct bands were observed for strains representing the BS8 groups 1, 2 and 3 , whereas multiple bands were observed for the strains belonging to the BS8 groups 4 and 5 (Fig. 3), suggesting the presence of a repetitive sequence in different regions of the genome. The cluster analysis resulted in two main groups (data not shown). The first group (which included strains belonging to RNA groups 1 and 5) is divided in three subgroups (BS8 1, 2 and 3). Within the second group (which included RNA groups 2, 3 and 4) six subgroups occurred (BS8 groups 4, 5, 6, 7, 8, 9). Considerable polymorphism was observed among South American strains which were found in all nine subgroups, whilst all the African strains were clustered in the same subgroup (Table 2). Similar results were obtained with the pBS6 probe. Cluster analysis (data not shown) of data obtained with this probe, allowed the distinction of the strains into 17 RFLP groups (Table 2). All strains contained the repetitive cloned sequence in pBS6 in high copy number (Fig. 4).

The plasmid probe pBSF2 was used to detect polymorphism among strains of $X$. campestris pv. manihotis (Fig. 5) and produced 26 different hybridization patterns. A high level of polymorphism was observed among RNA group 2 which included 13 Brazilian strains, one Venezuelan strain and one Mauritian strain (Table 2). Using the pBSF2 and pBS8 probes, no hybridization was observed with $X$. campestris pv. undulosa (strain UPB 670) and $X$. campestris pv. cassavae (strain HMB 29) genomic DNA. Hybridization with $X$. campestris pv. malvacearum (strain NCPPB 633) and $X$. campestris pv. phaseoli (strain CIAT 214) genomic DNA gave different patterns with pBSF2 and pBS8, respectively (data not shown), clearly distinct from those of $X$. campestris pv. manihotis defined above. pBS6 was not tested on these four strains. pBluescript vector DNA did not hybridize with $X$. campestris pv. manihotis genomic DNA.

\section{Pathogenic characteristics}

All the $X$. campestris pv. manihotis strains, except four strains (one Brazilian, one Ivory Coast and two Congolese strains), caused characteristic pathogenic symptoms on cassava plants. Variation in virulence was observed but was not related to the geographical origin of strains or to the RFLP groups defined above.

\section{Phenotypic features}

Starch hydrolysis was demonstrated for all the strains of $X$. campestris pv. manihotis tested. All African strains showed a limited ability to hydrolyse starch when compared to strains from South America. Strains originating from South America and Asia showed a strong amylase activity (Table 3 ). 


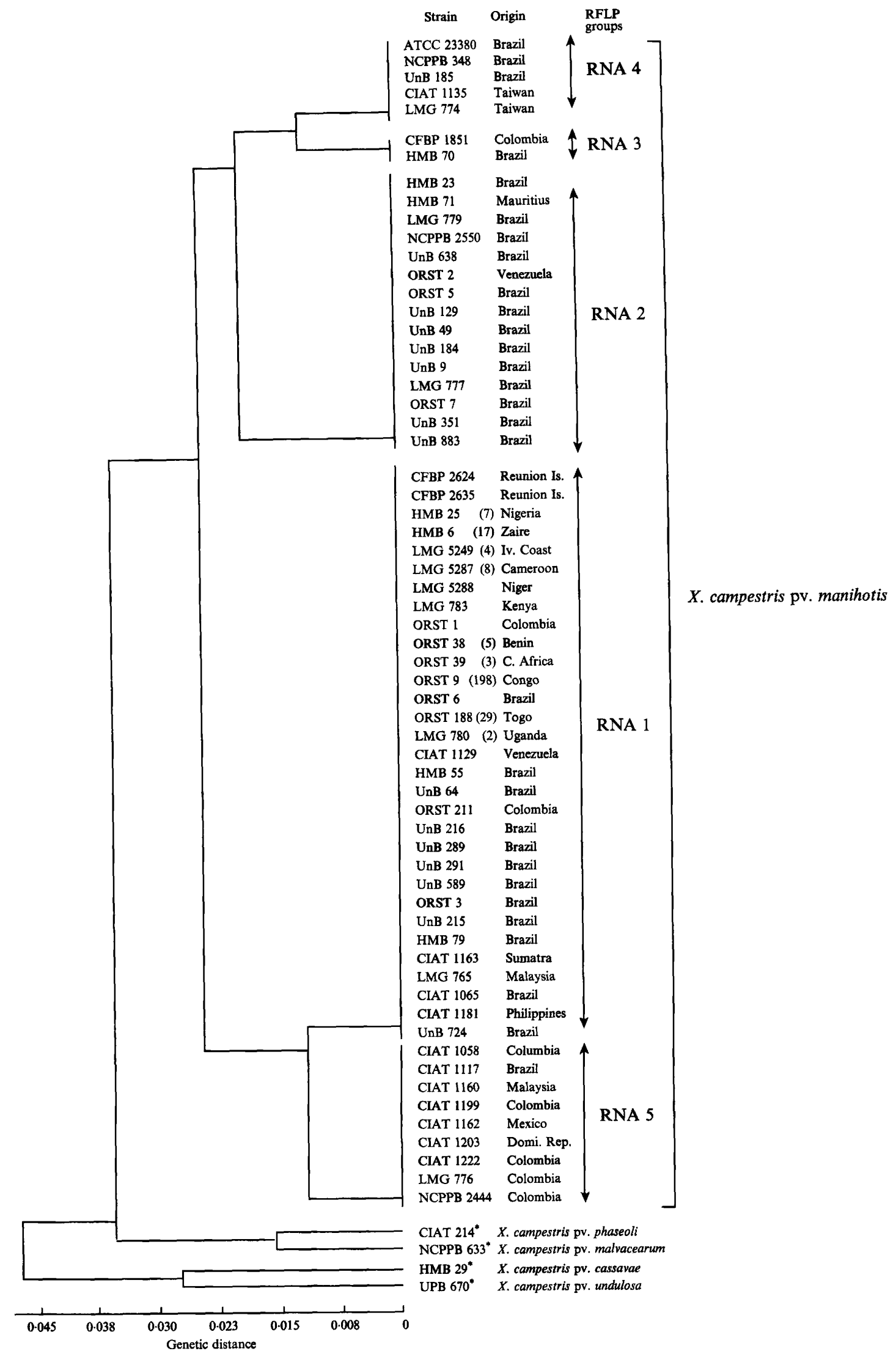


Table 2. Placement of strains of X. campestris pv. manihotis in RFLP groups based on four different DNA probes

\begin{tabular}{|c|c|c|c|c|c|}
\hline \multirow[b]{2}{*}{ Origin } & \multirow[b]{2}{*}{ Strain no. } & \multicolumn{4}{|c|}{ No. of RFLP groups with probe:* } \\
\hline & & rRNA & pBS8 & pBS6 & pBSF2 \\
\hline \multirow[t]{6}{*}{ Colombia } & LMG 776, NCPPB 2444 & 5 & 2 & 3 & 2 \\
\hline & ORST 1 & 1 & 3 & 6 & 11 \\
\hline & CIAT 1058, CIAT 1199 & 5 & 1 & 1 & 1 \\
\hline & CIAT 1222 & 5 & 2 & 2 & 3 \\
\hline & CFBP 1851 & 3 & 8 & 14 & 24 \\
\hline & ORST 211 & 1 & 2 & 4 & 6 \\
\hline \multirow[t]{2}{*}{ Venezuela } & ORST 2 & 2 & 4 & 10 & 19 \\
\hline & CIAT 1129 & 1 & 2 & 4 & 4 \\
\hline \multirow[t]{15}{*}{ Brazil } & $\begin{array}{l}\text { HMB } 055, \text { UnB } 64, \text { UnB } 216, \text { UnB } 289, \text { UnB } 291 \text {, } \\
\text { UnB } 589, \text { ORST } 3 \text {, HMB } 79 \text {, UnB } 215\end{array}$ & 1 & 2 & 4 & $\begin{array}{l}5,7,8,9 \\
10\end{array}$ \\
\hline & CIAT 1065 , UnB 724 & 1 & 2 & 5 & 6 \\
\hline & ORST 6 & 1 & 3 & 6 & 12 \\
\hline & NCPPB 2550, UnB 49, UnB 129, UnB 9, UnB 184 & 2 & 4 & 9 & $15,16,17$ \\
\hline & UnB 638 & 2 & 4 & 13 & 17 \\
\hline & HMB 023, LMG 779 & 2 & 4 & 10 & 20 \\
\hline & ORST 5 & 2 & 4 & 10 & 19 \\
\hline & UnB 833 & 2 & 4 & 7 & 23 \\
\hline & LMG 777 & 2 & 5 & 12 & 21 \\
\hline & ORST 7 & 2 & 6 & 11 & 22 \\
\hline & UnB 351 & 2 & 7 & 9 & 18 \\
\hline & HMB 70 & 3 & 8 & 14 & 24 \\
\hline & ATCC 23380, NCPPB 348 & 4 & 9 & 15 & 24 \\
\hline & UnB 185 & 4 & 9 & 16 & 25 \\
\hline & CIAT 1117 & 5 & 1 & 1 & 1 \\
\hline Mexico & CIAT 1162 & 5 & 2 & 2 & 2 \\
\hline Dominican Rep. & CIAT 1203 & 5 & 2 & 2 & 2 \\
\hline \multirow[t]{2}{*}{ Malaysia } & CIAT 1160 & 5 & 1 & 1 & 1 \\
\hline & LMG 765 & 1 & 2 & 5 & 5 \\
\hline Taiwan & CIAT 1135, LMG 774 & 4 & 9 & 17 & 26 \\
\hline Sumatra & CIAT 1163 & 1 & 2 & 5 & 5 \\
\hline Philippines & CIAT 1181 & 1 & 2 & 5 & 6 \\
\hline Mauritius & HMB 71 & 2 & 4 & 10 & 20 \\
\hline Reunion Island & CFBP 2624, CFBP 2635 & 1 & 3 & 6 & 14 \\
\hline Nigeria $\dagger$ & $\begin{array}{l}\text { HMB } 25 \text {, ORST } 42, \text { ORST } 43 \text {, CFBP } 1858, \\
\text { CFBP } 1859, \text { CFBP } 1860\end{array}$ & 1 & 3 & 6 & 11 \\
\hline Benin $\uparrow$ & ORST 34, ORST 35, ORST 36, ORST 37, ORST 38 & 1 & 3 & 6 & 11 \\
\hline Ivory Coast ${ }^{\dagger}$ & CFBP 1944, LMG 5249, ORST 55, ORST 56 & 1 & 3 & 6 & 11 \\
\hline Central Africa $\dagger$ & ORST 39 , ORST 40, ORST 41 & 1 & 3 & 6 & 11 \\
\hline Cameroun $\dagger$ & $\begin{array}{l}\text { LMG 5287, HMB 27, ORST } 212 \text {, ORST } 213 \text {, ORST } \\
214 \text {, ORST } 215 \text {, ORST } 216 \text {, ORST } 217\end{array}$ & 1 & 3 & 6 & 11 \\
\hline Uganda $†$ & LMG 780, LMG 782 & 1 & 3 & 6 & 13 \\
\hline Kenyat & LMG 783 & 1 & 3 & 6 & 11 \\
\hline Nigert & LMG 5288 & 1 & 3 & 6 & 11 \\
\hline Zairet & 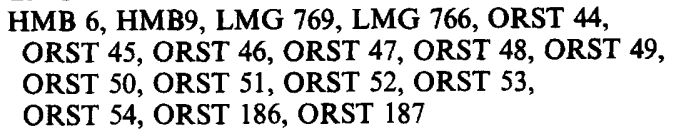 & 1 & 3 & 6 & 11 \\
\hline Congot & 198 strains ORST & 1 & 3 & 6 & 11,12 \\
\hline Togot & 29 strains ORST & 1 & 3 & 6 & 11,12 \\
\hline
\end{tabular}

* Each number represents one RFLP group (strains with identical RFLP patterns form a group). Numbers are not comparable across rows.

$\dagger$ African countries.

Fig. 2. Dendrogram of genetic distance using the computer program Restsite (Miller, 1992), showing the relationships among strains of $X$. campestris pv. manihotis based on RFLP analysis using AAF-labelled rRNA $16+23 \mathrm{~S}$ as a probe. Sixty-two representative strains of $X$. campestris pv. manihotis (out of the 326 used) were used in the construction of the dendrogram. The number of strains studied is indicated within parentheses. Four strains from others pathovars were also included. ${ }^{*}$, Unclustered strains. 


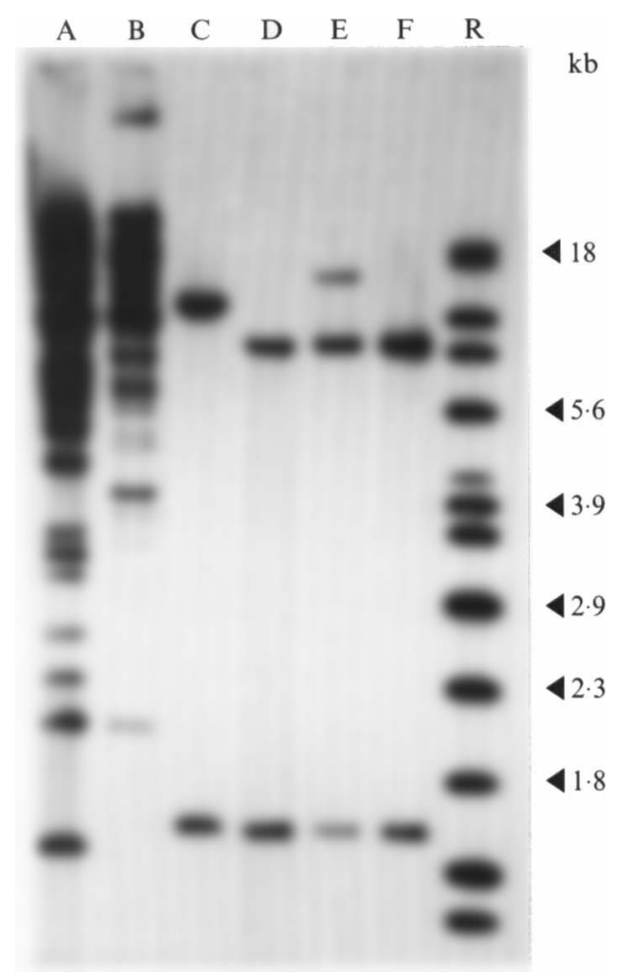

Fig. 3. Southern hybridization of EcoRI-digested genomic DNA of six strains of $X$. campestris pv. manihotis probed with ${ }^{32} \mathrm{P}$-labelled clone pBS8. Lanes: A, strain LMG 777 (Brazil), BS8 group 5; B, strain UnB 833 (Brazil), BS8 group 4; C, strain LMG 5287 (Cameroon), BS8 group 3; D, strain CIAT 1065 (Brazil), BS8 group 2; E, strain CIAT 1117 (Brazil), BS8 group 1; F, strain NCPPB 2444 (Colombia), BS8 group 2; R, molecular mass standard RaoulI.
Only minor differences for susceptibility towards antibiotics in vitro were noted. All the strains were resistant to three antibiotics (per disk: $300 \mathrm{U}$ polymixin $\mathrm{B}, 250 \mu \mathrm{g}$ sulfamide, $10 \mu \mathrm{g}$ ampicillin), and sensitive to (per disk) $10 \mu \mathrm{g}$ streptomycin, $30 \mu \mathrm{g}$ kanamycin, $15 \mu \mathrm{g}$ erythromycin, $30 \mu \mathrm{g}$ chloramphenicol, $30 \mu \mathrm{g}$ rifampicin and $30 \mu \mathrm{g}$ tetracycline. A variable response was observed with the other antibiotics, which was not related to the geographical origin of strains.

Growth on different carbon sources was similar for all strains tested: growth was observed on D-glucose, Dmannose, trehalose, cellobiose, fructose, saccharose, xylose and galactose. Poor or no growth was observed in basal medium supplemented with rhamnose, amidon, arabinose, erythritol, esculin, glycerol, lactose, maltose, raffinose, ribose and salicin.

\section{Discussion}

Berthier et al. (1993) reported that RFLP analysis with the rRNA probe could distinguish the pathovar manihotis from other pathovars, as well as from other xanthomonads. In this initial study involving 42 strains of $X$. campestris pv. manihotis it was established that there were three distinct RFLP patterns with the rRNA probe. All the strains from Africa gave the same pattern in contrast with the six strains from South America which gave three patterns (Berthier et al., 1993). This study has been extended here to a total of 326 strains of

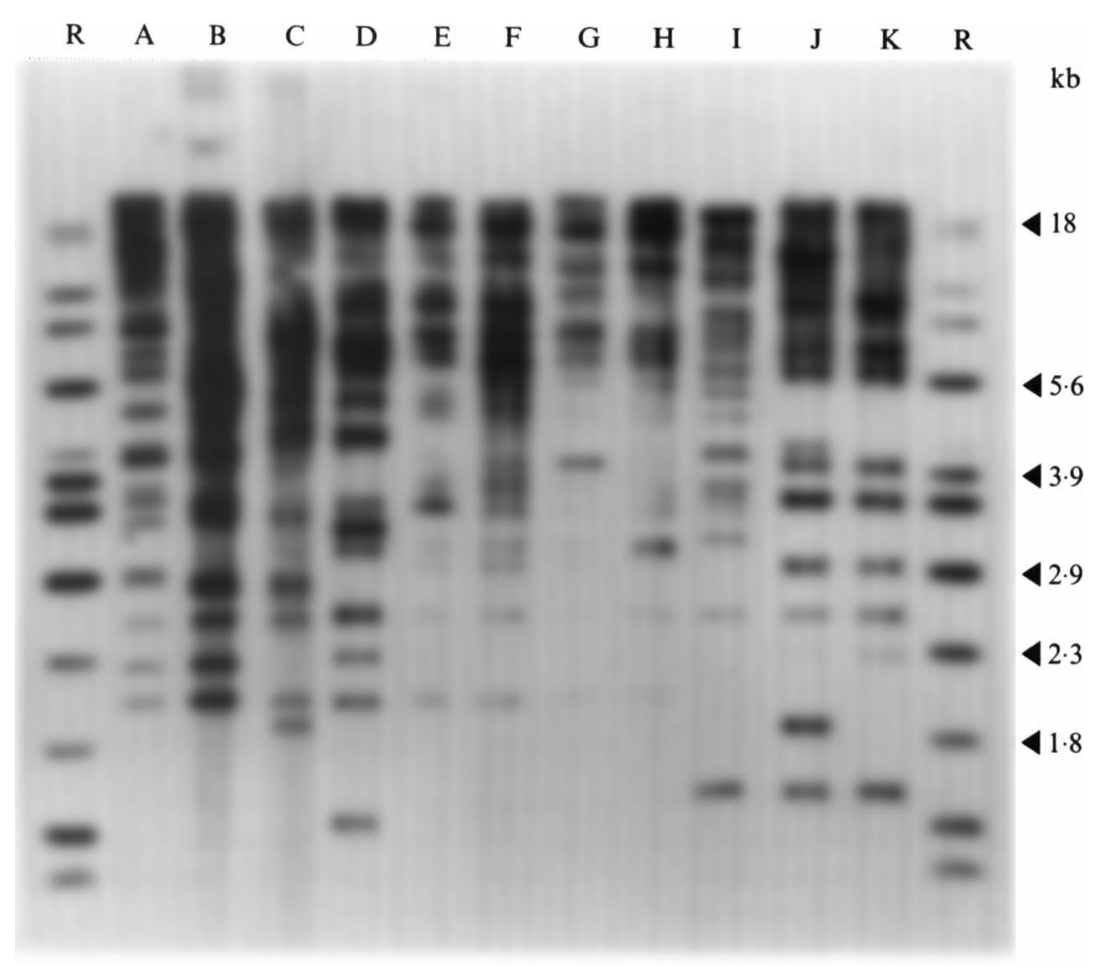

Fig. 4. Southern hybridization of EcoRI-digested genomic DNA of 11 strains of $X$. campestris pv. manihotis probed with ${ }^{32} \mathrm{P}$-labelled clone pBS6. Lanes: A, strain CIAT 1135 (Taiwan), BS6 group 17; B, strain UnB 185 (Brazil), BS6 group 16; C, strain CFBP 1851 (Colombia), BS6 group 14; D, strain LMG 777 (Brazil), BS6 group 12; E, strain LMG 779 (Brazil), BS6 group 10; F, strain NCPPB 2550 (Brazil), BS6 group 9; G, strain UnB 638 (Brazil), BS6 group 13; H, strain UnB 833 (Brazil), BS6 group 7; I, strain CFBP 2624 (Reunion Island), BS6 group 6; J, strain CIAT 1117 (Brazil), BS6 group 1; K, strain NCPPB 2444 (Colombia), BS6 group 3; R, molecular mass standard RaoulI. 
Fig. 5. Southern hybridization of EcoRI-digested genomic DNA of 14 strains of $X$. campestris pv. manihotis probed with ${ }^{32} \mathrm{P}$-labelled clone pBSF2. Lanes: A, strain LMG 777 (Brazil), BSF2 group 21; B, strain ORST 7 (Brazil), BSF2 group 22; C, strain HMB 023 (Brazil), BSF2 group 20; D, strain LMG 779 (Brazil), BSF2 group 20; E, strain HMB 71 (Brazil), BSF2 group 20; F, strain ORST 5 (Brazil), BSF2 group 19; G, strain ORST 2 (Venezuela), BSF2 group 19; H, strain LMG 5288 (Niger), BSF2 group $11 ; \mathrm{I}$, strain LMG 783 (Kenya), BSF2 group 11; J, strain LMG 780 (Uganda), BSF2 group 13; K, strain ORST 203 (Congo), BSF2 group 12; L, strain ORST 64 (Congo), BSF2 group 11; M, strain ORST 133F (Congo), BSF2 group 11; N, strain CFBP 2624 (Reunion Island), BSF2 group 14; R, molecular mass standard RaoulI.

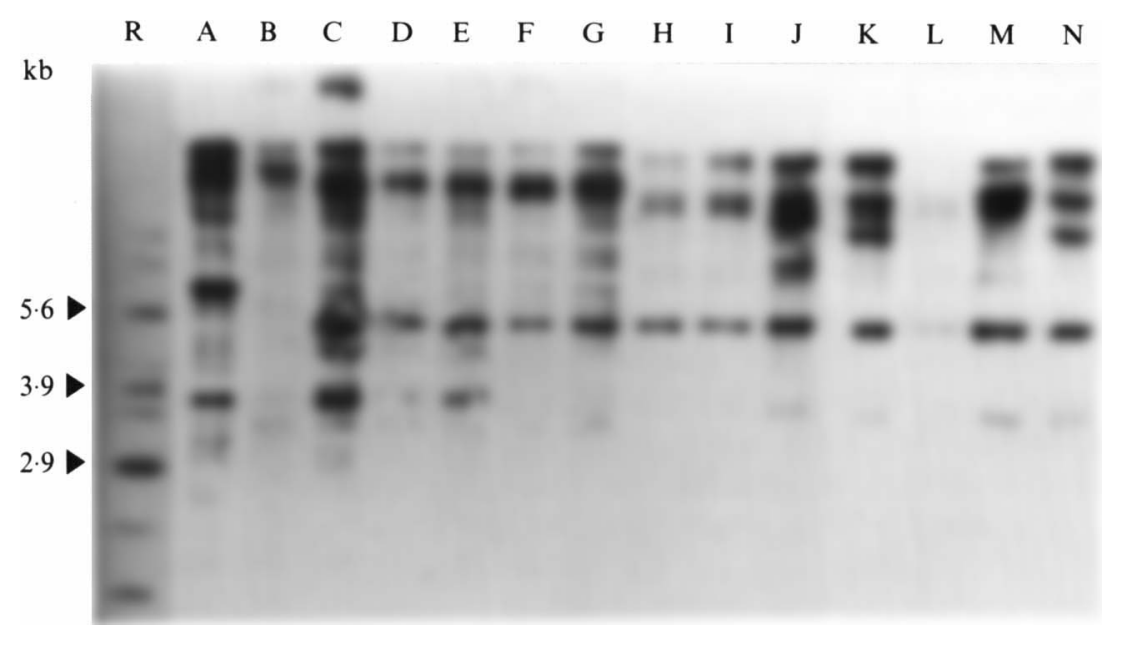

Table 3. Distribution of amylase activity among strains of $X$. campestris p $v$. manihotis

Amylase activity was assessed by clarity of zones surrounding the colony $(0-1.5 \mathrm{~cm}$, low amylase activity; $1.5-3 \mathrm{~cm}$, strong amylase activity).

\begin{tabular}{|c|c|c|c|c|}
\hline \multirow[b]{2}{*}{ Origin } & \multirow[b]{2}{*}{$\begin{array}{c}\text { RFLP } \\
\text { groups } \\
\text { with rRNA } \\
\text { probe }\end{array}$} & \multicolumn{3}{|c|}{ Number of strains: } \\
\hline & & Tested & $\begin{array}{c}\text { With strong } \\
\text { amylase } \\
\text { activity }\end{array}$ & $\begin{array}{c}\text { With low } \\
\text { amylase } \\
\text { activity }\end{array}$ \\
\hline \multicolumn{5}{|l|}{ Africa } \\
\hline Nigeria & 1 & 7 & 0 & 7 \\
\hline Benin & 1 & 5 & 0 & 5 \\
\hline Ivory Coast & 1 & 4 & 0 & 4 \\
\hline Congo & 1 & 198 & 0 & 198 \\
\hline Togo & 1 & 29 & 0 & 29 \\
\hline Zaire & 1 & 17 & 0 & 17 \\
\hline Central Africa & 1 & 3 & 0 & 3 \\
\hline Cameroon & 1 & 8 & 0 & 8 \\
\hline Uganda & 1 & 2 & 0 & 2 \\
\hline Kenya & 1 & 1 & 0 & 1 \\
\hline Niger & 1 & 1 & 0 & 1 \\
\hline Mauritius & 1 & 1 & 0 & 1 \\
\hline Reunion Island & 1 & 2 & 0 & 2 \\
\hline \multicolumn{5}{|l|}{ Asia } \\
\hline Taiwan & 4 & 1 & 1 & 0 \\
\hline Malaysia & 1,5 & 1 & 0 & 1 \\
\hline \multicolumn{5}{|l|}{ South America } \\
\hline Columbia & $1,3,5$ & 3 & 2 & 1 \\
\hline Venezuela & 1,2 & 1 & 1 & 0 \\
\hline Brazil & $1,2,3,4,5$ & 10 & 7 & 3 \\
\hline
\end{tabular}

$X$. campestris pv. manihotis from various geographical areas including 284 additional strains of African, Asian and Latin American origin. Using RFLP analysis, our results demonstrate that $X$. campestris pv. manihotis is more genetically diverse in South America than in Africa. A high level of polymorphism could be detected among South American strains with all four probes tested.
On the basis of the present data we have shown that the rRNA gene restriction pattern (ribotypes) allowed the distinction of geographical groups of $X$. campestris pv. manihotis. The RFLP patterns with the rRNA probe were as determined previously (Berthier et al., 1993), however two additional RFLP groups that corresponded to strains isolated in South America and Asia were characterized. Moreover, hybridization with the other cloned DNA probes revealed more genomic polymorphism than the rRNA probe. The probe pBS6 contains a repetitive DNA sequence present in many copies in DNA from all strains of $X$. campestris pv. manihotis tested. With the probe pBS8, the African strains were distinguished from Asian and South American strains in that DNA from African strains contained fewer copies of the repetitive element pBS8. Our results are very similar to those of Leach et al. (1992) who have used a repetitive element to measure the genetic diversity of the $X$. oryzae populations.

The DNA probes used in this study allowed the assessment of relatedness of different strains. Some strains were clustered in the same RFLP group with the plasmid (pBSF2) or genomic probes (pBS6, pBS8) used: Brazilian, Colombian and Malaysian strains; Mexican, Dominican and Colombian strains; Sumatran, Philippine, Malaysian, Brazilian and Colombian strains; Brazilian, Colombian and African strains. The fact that all the 274 African strains studied were clustered in the same RFLP group with South American strains is consistent with the hypothesis of the recent introduction of this pathogen from South America to African countries. Lack of polymorphism observed among African strains isolated in different geographical locations (West, Central and East Africa), demonstrate a clonal population structure for the pathogen. The results suggest that these strains have not as yet diversified at the chromosomal level. RFLP analysis of the 196 strains 
from Congo showed no polymorphism amongst the strains. This is inspite of the fact that the strains were collected from different ecological zones, over a period of 15 years in the Congo (1976-1991) at different seasons (both rainy and dry seasons) and even from different cultivars of the host plant. This shows that none of these different cultivars offered sufficient selection pressure to result in any detectable genetic changes. Nevertheless, the probe from a DNA plasmid fragment (pBSF2) revealed some DNA polymorphisms in African strains. This is not surprising since some plasmids can be conjugatively transferred to facilitate genetic exchange in bacterial strains (Coplin, 1989; Eberhard, 1990). Plasmid DNA RFLP profiles were also a more sensitive measure of diversity in bacterial strains as shown in $X$. campestris pv. citri (Pruvost et al., 1992).

The cloned plasmid DNA fragment (pBSF2) hybridized to total genomic DNA of some pathovars of $X$. campestris with pathovar-specific patterns and allowed distinction of polymorphism within strains of these pathovars (V. Verdier, unpublished data). The pBSF2 clone could possibly be used to identify some strains from other pathovars of $X$. campestris.

The high level of diversity observed in the genome of South American strains could be a consequence of the host genotype diversity, confirming an accepted concept in the host-pathogen coevolution and in biotype selection (Leonard \& Czochor, 1980). A few reports have shown that genetic diversity among cassava plants was extensive in the South American areas, whereas it was more restricted in African countries (Lefevre, 1988). This is probably because cassava is a crop native to South America and was introduced into Africa only in the 16th and 18th centuries by the Portuguese traders. Recent introduction of cassava plants has been also accomplished by different 'International Centers' from Colombia (CIAT) to Nigeria (IITA) via seeds, cuttings and in vitro plantlets.

RFLP analysis is more precise and more discriminative to assess genetic diversity, than other methods such as serology, phenotypic analysis and fatty acid profiling. On the basis of SDS-PAGE analyses of cellular protein, Vauterin et al. (1991) could not find any obvious differences among 14 strains of $X$. campestris pv. manihotis from different geographical origins. These strains were included in the present study and the RFLP analysis enabled the detection of genetic groups within these strains.

Biochemical and physiological variations within the pathovar have been reported but no correlation was observed between the characteristics studied and virulence or geographic origin (Maraite et al., 1981; Van den Mooter et al., 1987; Verdier, 1988; Grousson et al., 1990). Our results on the phenotypic characteristics agree with these previous reports and have shown that only minor differences were evident in the biochemical features tested. The only biochemical characteristic that allowed a clear distinction between geographical groups was the ability to hydrolyse starch. Such results have been described for X. campestris pv. manihotis (Maraite et al., 1981) and also for $X$. campestris pv. vasculorum in which differentiation of Eastern and Southern African strains was possibly using starch hydrolysis (Qhobela \& Calflin, 1992).

We have evaluated the potential use of the RFLP technique to describe the pathogen population structure over time and space, in a worldwide collection of $X$. campestris pv. manihotis, as well as in an African population (Congo). The different probes used in this study are extremely useful tools for following the genetic evolution of strains. RFLP data suggests that all African strains and Asian strains have a common centre of origin in the South American cassava areas. It is likely that dissemination of this pathogen has been brought about by humans, either with infected cuttings as reported by Kwage (1982) in Sudan or with infected seeds (Elango \& Lozano, 1980).

Presently, control of the disease is based essentially on the use of cassava-resistant germ plasma. Information on genetic variability of the pathogen and consequently its potential for adaptation to new cassava cultivars will give the crop breeders a broader knowledge in the development of new, more resistant cultivars.

The authors gratefully acknowledge Dr C. Boucher (INRA, Toulouse, France) and D. Chevrier (Institut Pasteur, Paris, France) for advice and discussions. They thank M. Levy and E. Ganga (Orstom, Brazzaville, Congo) for their technical assistance. They also thank $\mathrm{Dr}$ H. Maraite (Université Catholique de Louvain, Belgium), Dr A. Takatsu (Universidade de Brasilia, Brazil) and Dr J. C. Lozano (CIAT, Cali, Colombia) for providing isolates of $X$. campestris pv. manihotis, and Dr M. Lourd (Orstom, France) for providing diseased plant materials from Cameroon. We also thank Dr C. A. N. Okoli for a presubmission review of the manuscript.

\section{References}

Ber thier, Y., Verdier, V., Guesdon, J. L., Chevrier, D., Denis, J. B., DecouX, G. \& Lemattre, M. (1993). Characterization of Xanthomonas campestris pathovars by rRNA gene restriction patterns. Applied and Environmental Microbiology 59, 851-859.

BONDAR, G. (1912). Um nova molestia bacteriana das hastes da mandioca. Chacaras e Quintaes 5, 15-18.

Booth, R. H. \& Lozano, J. C. (1978). Cassava bacterial blight in South East Asia. Plant Disease Reporter 62, 529-530.

Boucher, C., Barberis, P., Trigalet, A. \& Demery, D. (1985). Transposon mutagenesis of Pseudomonas solanacearum: isolation of Tn5-induced avirulent mutants. Journal of General Microbiology 131, 2449-2457.

CoOK, D., Barlow, E. \& SequeIra, L. (1989). Genetic diversity of Pseudomonas solanacearum: detection of restriction fragment length polymorphisms with DNA probes that specify virulence and the hypersensitive response. Molecular Plant-Microbe Interactions 2, 113-121. 
COOK, D., BARLow, E. \& SEQueIRA, L. (1991). DNA probes as tools for the study of host-pathogen evolution: the example of Pseudomonas solanacearum. In Advances in Molecular Genetics of Plant-Microbe Interactions, pp. 103-108. Edited by H. Hennecke \& D. P. S. Verma. The Netherlands: Kluwer Academic Publishers.

Coplin, D. (1989). Plasmids and their role in the evolution of plant pathogenic bacteria. Annual Review of Phytopathology 27, 187-212.

DenNy, T. P., Gilmour, M. N. \& Selander, R. K. (1988). Genetic diversity and relationships of two pathovars of Pseudomonas syringae. Journal of General Microbiology 134, 1949-1960.

EBERHARD, W. (1990). Evolution in bacterial plasmids and levels of selection. Quarterly Review of Biology 65, 3-22.

Elango, F. \& Lozano, J. C. (1980). Transmission of Xanthomonas manihotis in seeds of cassava (Manihot esculenta). Plant Disease 64, 784-786.

Gabriel, D. W., Hunter, J. E., Kingsley, M. T., Muller, J. W. \& LAZO, G. R. (1988). Clonal population structure of Xanthomonas campestris and genetic diversity among citrus canker strains. Molecular Plant-Microbe Interactions 1, 59-65.

Grimont, F., Chevrier, D., Grimont, P. A. D., Lefevre, M. \& GuESDON, J. L. (1989). Acetylaminofluorene-labelled ribosomal RNA for use in molecular epidemiology and taxonomy. Annales de IInstitut Pasteur Microbiologie 140, 447-454.

Grousson, F., Pages, J. \& Boher, B. (1990). Etude de la variabilité d'un agent pathogène, Xanthomonas campestris pv, manihotis, par l'analyse factorielle multiple. Agronomie (Paris) 4, 627-640.

HARTUNG, J. S. \& Civerolo, E. L. (1989). Restriction fragment length polymorphisms distinguish Xanthomonas campestris strains isolated from Florida citrus nurseries. Phytopathology 79, 793-799.

HaYWARD, A. C. (1964). Characteristics of Pseudomonas solanacearum. Journal of Applied Bacteriology 27, 265-277.

KWAGE, S. L. (1982). Bacterial blight on cassava. FAO Plant Protection Bulletin 30, 82-83.

LAZO, G. R. \& GABRIEL, D. W. (1987). Conservation of plasmid DNA sequences of pathovar identification of strains of Xanthomonas campestris. Phytopathology 77, 448-453.

LeACH, J. E., White, F. F., RhoAds, M. L. \& LeUng, H. (1990). A repetitive DNA sequence differentiates Xanthomonas campestris pv. oryzae from other pathovars of $X$. campestris. Molecular PlantMicrobe Interactions 3, 238-246.

Leach, J. E., Rhoads, M. L., Vera Cruz, C. M., White, F. F., Mew, T. W. \& LEUNG, H. (1992). Assessment of genetic diversity and population structure of Xanthomonas oryzae pv. oryzae with a repetitive DNA element. Applied and Environmental Microbiology 58, 2188-2195.

LEFEVRE, F. (1988). Ressources génétiques et amélioration du manioc, Manihot esculenta Crantz en Afrique. Thesis, INA-PG, Paris, France.

LEONARD, K. J. \& CZOCHOR, R. J. (1980). Theory of genetic interactions among populations of plants and their pathogens. Annual Review of Phytopathology 18, 237-258.

LozANo, J. C. \& SequeIRA, L. (1974a). Bacterial blight of cassava in Colombia: etiology. Phytopathology 64, 74-82.

LozANo, J. C. \& SEQueIRA, L. (1974b). Bacterial blight of cassava in Colombia: epidemiology and control. Phytopathology 64, 83-88.

Maniatis, T., Fritsch, E. F. \& SambrooK, J. (1982). Molecular
Cloning: A Laboratory Manual. Cold Spring Harbor, NY: Cold Spring Harbor Laboratory.

MARAITE, H. \& MEYER, J. A. (1975). Xanthomonas manihotis (Arthaud, Berthet) Starr causal agent of bacterial wilt and leaf spot of cassava in Zaire. Proceedings of the National Academy of Sciences of the United States of America 21, 27-37.

Maraite, H., Weyns, J., Yinkwan, O., Lipembra, P. \& Perreaux, D. (1981). Physiological and pathogenic variations in Xanthomonas campestris pv. manihotis. In: Proceedings of the Fifth International Conference on Plant Pathogenic Bacteria, pp. 358-368. Cali, Colombia: CIAT.

MilleR, J. C. (1992). Restsite: a phylogenetic program that sorts restriction data. Journal of Heredity 32, 262-263.

NEI, M. (1987). Molecular Evolutionary Genetics. New York: Columbia University Press.

Pruvost, O., Hartung, J. S., Civerolo, E. L., Dubois, C. \& Perrier, $X$. (1992). Plasmid DNA fingerprints distinguish pathotypes of Xanthomonas campestris pv. citri, the causal agent of citrus bacterial canker disease. Phytopathology 82, 485-490.

Qhobela, M. \& ClafLin, L. E. (1992). Eastern and Southern African strains of Xanthomonas campestris pv. vasculorum are distinguishable by restriction fragment length of DNA and polyacrylamide gel electrophoresis of membrane proteins. Plant Pathology 41, 113-121.

Qhobela, M., Claflin, L. E. \& Nowell, D. C. (1990). Evidence that Xanthomonas campestris pv. zeae can be distinguished from other pathovars capable of infecting maize by restriction fragment length polymorphism of genomic DNA. Canadian Journal of Plant Pathology 12, 183-186.

Qhobela, M., Leach, J. E., Claflin, L. E. \& Pearson, D. L. (1991). Characterization of strains of Xanthomonas campestris pv. holcicola by PAGE of membrane proteins and by REA and RFLP analysis of genomic DNA. Plant Disease 75, 32-36.

Scieux, C., Grimont, F., Regnault, B. \& Grimont, P. D. A. (1992). DNA fingerprinting of Chlamydia trachomatis by use of ribosomal RNA, oligonucleotide and randomly cloned DNA probes. Annales de I Institut Pasteur Research in Microbiology 143, 755-765.

SOUTHERN, E. M. (1975). Detection of specific sequences among DNA fragments separated by gel electrophoresis. Journal of Molecular Biology 98, 503.

Van den Mooter, M., Maraite, H., Meiresonne, L., Swings, J., Gillis, M., Kersters, K. \& De LeY, J. (1987). Comparison between Xanthomonas campestris pv. manihotis (ISPP List 1980) and $X$. campestris pv. cassavae (ISPP List 1980) by means of phenotypic, protein electrophoretic, DNA hybridization and phytopathological techniques. Journal of General Microbiology 133, 57-71.

VAuTERIN, L., Swings, J. \& Kersters, K. (1991). Grouping of Xanthomonas campestris pathovars by SDS-PAGE of proteins. Journal of General Microbiology 137, 1677-1687.

VerDier, V. (1988). Contribution à l'étude de la variabilité de Xanthomonas campestris pv. manihotis (Arthaud Berthet et Bondar) Starr agent causal de la bactériose vasculaire du manioc (Manihot esculenta Crantz). Thesis, Université de Paris Sud, Orsay, France.

Williams, R. J., Agboola, S. D. \& SChNeider, R. W. (1973). Bacterial wilt of cassava in Nigeria. Plant Disease Reporter 57, 824-827.

Xu, G. W. \& Gonzales, C. F. (1991). Plasmid, genomic, and bacteriocin diversity in US strains of Xanthomonas campestris pv. oryzae. Phytopathology 81, 628-631. 